\title{
Effect of the Fermented Soybean Product "Natto" on the Composition and Metabolic Activity of the Human Fecal Flora
}

\author{
Atsushi Terada, Masashige Yamamoto and Eiji Yoshimura \\ (Department of Food Hygiene, Nippon Veterinary and Animal Science University, \\ 1-7-1 Kyonan-cho, Musashino-shi, Tokyo 180-0023) \\ (Received December 1, 1999) \\ (Accepted February 4, 2000)
}

\begin{abstract}
The effects of the fermented soybean product "Natto" on the composition and metabolic activity were studied in seven healthy volunteers (22-49 years of age) who ingested $50 \mathrm{~g}$ of Natto/day for 14 days. During Natto consumption, the counts of Bacillus subtilis (B. natto; $p<0.001)$ and Bifidobacterium $(p<0.05)$ were significantly increased, except for the numbers of Bifidobacterium in two volunteers, whereas the counts and the frequency of occurrence of lecithinase-positive clostridia $(p<0.05)$, including Clostridium perfringens were significantly decreased, when compared to the values before the consumption. The decreased tendency in the counts of Enterobacteriaceae and the increased tendency in the detection rate of $B$. subtilis were observed during the consumption, compared to the values before the consumption. No detectable changes occurred in the counts of other organisms throughout the experimental periods.

The amounts of fecal acetic acid $(p<0.05)$ during the consumption, and total organic acids and succinic acid $(p<0.05)$ on day 14 of the consumption were significantly increased when compared to the values before and after the consumption. Fecal concentrations of phenol, ethylphenol, and skatol $(p<0.05)$ were significantly decreased during the consumption. Fecal ammonia and cresol $(p<0.05)$ were significantly decreased on day 14 of the consumption. Fecal $\mathrm{pH}$ values $(p<0.05)$ were significantly decreased on day 14 of the consumption. The odor of the feces was slightly reduced during the consumption.
\end{abstract}

Key words: Fecal flora, Fecal metabolic products, Natto (The fermented soybean product)

\section{Introduction}

Recently, functional foods such as probiotics, prebiotics and biogenics are being actively developed, and were recognized in 153 foods by the Japanese Ministry of Welfare on July 23, 1999. "Natto" is a traditional Japanese food made from soybeans by the fermentation of Bacillus subtilis ("B. natto"), and has both probiotic and biogenic actions. Soybeans have various oligosaccharides such as raffinose and stachyose ${ }^{11)}$, isoflavones such as genistin and genistein ${ }^{5)}$, dietary fibre ${ }^{4,20)}$ and high protein ${ }^{12}$. On the other hand, Natto has various ingredients such as amino $\operatorname{acids}^{34)}$, vitamin $\mathrm{B}^{33)}$ and vitamin $\mathrm{K}^{25)}$, and oligosaccharides such as melibiose and manninotriose ${ }^{11)}$ that are increased by fermentation.

Various effects of Natto as a medical food are known, including the prevention of high blood pressure and heart disease with nattokinase ${ }^{24)}$, the lowering of cholesterol with soybean protein ${ }^{12)}$, antibacterial activity against Escherichia coli with dipikorin acids ${ }^{23)}$, the inhibition of cancer with isoflavones ${ }^{11}$, the induction of interferon with toxin of gram-positive bacteria ${ }^{20)}$ and the reduction of soybean allergenicity with substances produced in the fermentation process of Natto ${ }^{35)}$.

Hara et $a l^{7}{ }^{7}$ ) showed that raffinose and soybean oligosaccharides selectively enhanced the growth of Bifidobacterium, except for Bifidobacterium bifidum in vitro as those in stachyose ${ }^{9}$. Minami et al. ${ }^{13)}$ observed that raffinose is utilized by $49 \%$ of 37 Enterobacteriaceae strains, and stachyose by $19 \%$ of the strains. Tsuchihashi et $a .^{33)}$ demonstrated that the addition of $0.5 \%$ Bacillus selectively 
Table 1. Experimental schedule

\begin{tabular}{|c|c|c|c|c|}
\hline & \multirow{2}{*}{$\frac{\text { Before consumption }}{\text { Day } 0}$} & \multicolumn{2}{|c|}{ During consumption } & \multirow{2}{*}{$\frac{\text { After consumption }}{\text { Day } 7}$} \\
\hline & & Day 7 & Day 14 & \\
\hline Week & $\leftarrow 2 \rightarrow$ & $\leftarrow 1 \rightarrow$ & $\leftarrow 1 \rightarrow$ & $\leftarrow 1 \rightarrow$ \\
\hline Natto intake (g/day) & 50 & 50 & 50 & 50 \\
\hline Sampling day & 0 & 7 & 14 & 7 \\
\hline \multicolumn{5}{|l|}{ Item for analysis; } \\
\hline Water content $(\%)$ & * & * & * & * \\
\hline $\mathrm{pH}$ & * & * & $*$ & * \\
\hline Fecal weight (g) & $*$ & $*$ & * & * \\
\hline Fecal flora & * & $*$ & * & $*$ \\
\hline $\mathrm{SCFA}(\mathrm{mg} / \mathrm{g})$ & $*$ & $*$ & $*$ & $*$ \\
\hline Ammonia $(\mu \mathrm{g} / \mathrm{g})$ & $*$ & $*$ & $*$ & $*$ \\
\hline Sulfide $(\mu \mathrm{g} / \mathrm{g})$ & $*$ & $*$ & $*$ & $*$ \\
\hline Phenols $(\mu \mathrm{g} / \mathrm{g})$ & $*$ & $*$ & $*$ & * \\
\hline Indole $(\mu \mathrm{g} / \mathrm{g})$ & $*$ & $*$ & $*$ & $*$ \\
\hline
\end{tabular}

*: Items examined.

SCFA: Short chain fatty acids.

Table 2. The media and culture methods for comprehensive investigation of intestinal flora

\begin{tabular}{|c|c|c|c|}
\hline Medium & Organisms enumerated & Incubation method & Incubation at $37^{\circ} \mathrm{C}$ \\
\hline \multicolumn{4}{|l|}{ Non-selective media } \\
\hline EG agar & Anaerobes 7 & Steel wool method & \multirow{2}{*}{3 days } \\
\hline $\mathrm{BL}$ agar & Anaerobes $]$ & replaced air with $\left.\mathrm{CO}_{2}\right]$ & \\
\hline Trypticase soy blood agar & Aerobes & Air & $1-2$ days \\
\hline \multicolumn{4}{|l|}{ Selective media } \\
\hline BS agar & Bifidobacteria & \multirow{5}{*}{$\begin{array}{l}\text { Steel wool method } \\
\text { replaced air with } \mathrm{CO}_{2}\end{array}$} & \multirow{5}{*}{3 days } \\
\hline ES agar & Eubacteria & & \\
\hline NBGT agar & Bacteroidaceae & & \\
\hline Neomycin Nagler agar & Clostridia & & \\
\hline VS agar & $\begin{array}{l}\text { Veillonellae and } \\
\text { Peptostreptococci }\end{array}$ & & \\
\hline LBS agar (modified) & Lactobacilli & Replaced air with $\mathrm{CO}_{2}$ & 2 days \\
\hline DHL agar & Enterobacteriaceae $]$ & & \multirow[t]{2}{*}{1 day } \\
\hline TATAC agar & Streptococci & & \\
\hline PEES agar & Staphylococci & Air & \multirow{3}{*}{2 days } \\
\hline NAC agar & Pseudomonas & & \\
\hline Potato dextrose agar & Yeasts and molds & & \\
\hline \multicolumn{4}{|l|}{ Media after heat treatment } \\
\hline $\mathrm{BL}$ agar and $\mathrm{CW}$ agar & Clostridia & $\begin{array}{l}\text { Steel wool method } \\
\text { replaced air with } \mathrm{CO}_{2}\end{array}$ & 2 days \\
\hline
\end{tabular}

enhanced the growth of Bifidobacterium in rat ceca. Some oligosaccharides in human were also observed to have a enhancing on Bifidobacterium ${ }^{2,8,9,18)}$ and a deodorizing effect on fecal odor ${ }^{7,9,29)}$.

The present study was carried out to evaluate the effects of Natto on fecal flora, fecal concentrations of putrefactive products and short chain fatty acids (SCFA), fecal pH, weight and moisture, all of which are related to the health promotion and the offensive odor of feces in humans.

\section{Materials and Methods}

\section{Subjects and diet}

Seven subjects were chosen from healthy male volunteers (aged 22-49 y). None of the subjects received medication and foods with abundant viable cultures for 14 days prior to or during the experiment.

Natto prepared for this study was a commercially-prepared boiled soybean product fermented by $B$. subtilis and its compositions was $B$. subtilis $4.9 \times 10^{9} / \mathrm{g}$, energy $84.0 \mathrm{kcal}$, protein $7.8 \mathrm{~g}$, fat 4.6 
Table 3. Effect of Natto consumption on anaerobic fecal flora of seven human volunteers

\begin{tabular}{|c|c|c|c|c|}
\hline \multirow{2}{*}{ Organism } & \multirow{2}{*}{$\frac{\text { Before consumption }}{\text { Day } 0}$} & \multicolumn{2}{|c|}{ During consumption } & \multirow{2}{*}{$\begin{array}{c}\text { After consumption } \\
\text { Day } 7\end{array}$} \\
\hline & & Day 7 & Day 14 & \\
\hline Total anaerobes & $10.65 \pm 0.14^{\mathrm{a}}$ & $10.64 \pm 0.11$ & $10.64 \pm 0.20$ & $10.53 \pm 0.22$ \\
\hline Bifidobacterium & $\begin{array}{c}9.84 \pm 0.27 \\
(100)^{\mathrm{b}}\end{array}$ & $\begin{array}{c}10.21 \pm 0.20 * \\
(100)\end{array}$ & $\begin{array}{c}10.24 \pm 0.27^{*} \\
(100)\end{array}$ & $\begin{array}{c}9.85 \pm 0.24 \\
(100)\end{array}$ \\
\hline Bacteroidaceae & $\begin{array}{l}10.52 \pm 0.10 \\
(100)\end{array}$ & $\begin{array}{c}10.40 \pm 0.14 \\
(100)\end{array}$ & $\begin{array}{c}10.38 \pm 0.14 \\
(100)\end{array}$ & $\begin{array}{c}10.38 \pm 0.22 \\
(100)\end{array}$ \\
\hline Eubacterium & $\begin{array}{l}9.45 \pm 0.48 \\
\quad(100)\end{array}$ & $\begin{array}{l}9.17 \pm 0.32 \\
\quad(100)\end{array}$ & $\begin{array}{l}9.12 \pm 0.44 \\
\quad(100)\end{array}$ & $\begin{array}{l}8.92 \pm 0.62 \\
(100)\end{array}$ \\
\hline Peptococcaceae & $\begin{array}{l}8.92 \pm 0.93 \\
(100)\end{array}$ & $\begin{array}{c}8.82 \pm 0.91 \\
(100)\end{array}$ & $\begin{array}{l}8.72 \pm 0.45 \\
\quad(100)\end{array}$ & $\begin{array}{c}8.58 \pm 0.74 \\
(100)\end{array}$ \\
\hline Megasphaera & $\begin{array}{c}8.63 \pm 0.50 \\
(57)\end{array}$ & $\begin{array}{c}8.47 \pm 0.57 \\
(43)\end{array}$ & $\begin{array}{c}8.59 \pm 0.29 \\
(43)\end{array}$ & $\begin{array}{c}8.38 \pm 0.49 \\
(43)\end{array}$ \\
\hline Veillonella & $\begin{array}{c}6.40 \pm 0.70 \\
(43)\end{array}$ & $\begin{array}{c}6.63 \pm 0.32 \\
(43)\end{array}$ & $\begin{array}{c}6.70 \pm 0.33 \\
(43)\end{array}$ & $\begin{array}{c}6.50 \pm 0.80 \\
(57)\end{array}$ \\
\hline \multicolumn{5}{|l|}{ Clostridium } \\
\hline Lecithinase-positive & $\begin{array}{l}5.09 \pm 0.53 \\
\quad(100)\end{array}$ & $\begin{array}{c}4.15 \pm 0.32^{*} \\
(43)^{*}\end{array}$ & $\begin{array}{c}3.29 \pm 1.07^{*} \\
(43)^{*}\end{array}$ & $\begin{array}{c}3.95 \pm 1.21 \\
(57)\end{array}$ \\
\hline Lecithinase-negative & $\begin{array}{c}8.80 \pm 0.64 \\
(86)\end{array}$ & $\begin{array}{c}8.18 \pm 0.52 \\
(57)\end{array}$ & $\begin{array}{c}8.42 \pm 0.55 \\
\quad(57)\end{array}$ & $\begin{array}{c}9.02 \pm 0.52 \\
\quad(86)\end{array}$ \\
\hline Lactobacillus & $\begin{array}{c}6.61 \pm 1.14 \\
(86)\end{array}$ & $\begin{array}{l}7.43 \pm 1.19 \\
(100)\end{array}$ & $\begin{array}{l}7.49 \pm 0.65 \\
(100)\end{array}$ & $\begin{array}{l}7.29 \pm 1.64 \\
(100)\end{array}$ \\
\hline
\end{tabular}

${ }^{\mathrm{a}}$ : Data expressed as mean log number per gram feces \pm S. D.

${ }^{\mathrm{b}}$ : Figures in parentheses are frequency of occurrence (\%).

Significant difference from the counts before consumption; ${ }^{*} p<0.05, * * p<0.001$.

Significant difference from frequency of occurrence before consumption; ${ }^{*} p<0.05$.

$\mathrm{g}$, carbohydrate $3.4 \mathrm{~g}$, natrium $1 \mathrm{mg}$, and moisture $29.5 \mathrm{~g}$. The volunteers consumed $50 \mathrm{~g} / \mathrm{day}$ of Natto for 14 days during the experiment, as shown in Table 1. This work was performed in accordance with the Helsinki Declaration as updated in Tokyo, 1975.

\section{Collections of specimens}

Freshly voided fecal specimens were collected on days 0 before the consumption, day 7 and 14 during the consumption, and day 7 after the consumption. The specimens were immediately transported at $4^{\circ} \mathrm{C}$ to the laboratory for analysis. The fecal flora, bacterial metabolites, weight, moisture content and $\mathrm{pH}$ value were analyzed within $3 \mathrm{hr}$. The remainder of the samples were frozen at $-80^{\circ} \mathrm{C}$ for later analysis of bacterial metabolites.

\section{Analysis of specimens}

Analysis of fecal microflora was carried out by using the methods and media of Mitsuoka et al. ${ }^{16)}$ and the heat treatment of Terada $e t a l .^{28)}$ as shown in Table 2. The bacterial count per gram wet weight of fecal material was calculated and converted to a logarithmic equivalent.

Fecal amounts of SCFA were analyzed by high-performance liquid chromatography using the methods of Hara et al. ${ }^{7}$ Fecal concentrations of ammonia and sulfide were determined by potentiometer ILO-30 (DKK Co., Ltd., Tokyo) with an ammonia gas-sensing electrode (DKK Co., Ltd., Tokyo) and with a sulfide electrode 7100 (DKK Co., Ltd., Tokyo) using the methods of Terada et al. ${ }^{32}$, respectively. Fecal indole and phenols were examined by gas chromatography using the methods of Yoshihara ${ }^{36)}$.

Fecal $\mathrm{pH}$ values were measured with a flat glass-electrode (DKK Co., Ltd., Tokyo). Fecal water content were determinated using $1 \mathrm{~g}$ samples, which were weighed before and after drying in a vacuum oven at $105^{\circ} \mathrm{C}$ for $2 \mathrm{hr}$ by infrared moisture gauge FD-230 type (Ketto Science Lab., Tokyo). The weight of fecal output for $24 \mathrm{hr}$ was measured for 3 consecutive days, including the days of sampling for the bacterial analyses. 
Table 4. Effect of Natto consumption on aerobic fecal flora of seven human volunteers

\begin{tabular}{|c|c|c|c|c|}
\hline \multirow{2}{*}{ Organism } & \multirow{2}{*}{$\begin{array}{c}\text { Before consumption } \\
\text { Day } 0\end{array}$} & \multicolumn{2}{|c|}{ During consumption } & \multirow{2}{*}{$\begin{array}{c}\text { After consumption } \\
\text { Day } 7\end{array}$} \\
\hline & & Day 7 & Day 14 & \\
\hline Total aerobes & $8.21 \pm 0.43$ & $8.68 \pm 0.33$ & $8.33 \pm 0.28$ & $8.19 \pm 0.46$ \\
\hline Enterobacteriaceae & $\begin{array}{c}8.12 \pm 0.69 \\
(100)\end{array}$ & $\begin{array}{c}7.41 \pm 0.55 \\
(100)\end{array}$ & $\begin{array}{c}7.57 \pm 0.20 \\
(100)\end{array}$ & $\begin{array}{c}7.80 \pm 0.31 \\
(100)\end{array}$ \\
\hline Streptococcus & $\begin{array}{c}7.48 \pm 0.84 \\
(100)\end{array}$ & $\begin{array}{c}7.78 \pm 0.86 \\
(100)\end{array}$ & $\begin{array}{c}7.31 \pm 0.67 \\
(100)\end{array}$ & $\begin{array}{c}7.96 \pm 0.63 \\
(100)\end{array}$ \\
\hline Staphylococcus & $\begin{array}{l}3.69 \pm 0.80 \\
\quad(100)\end{array}$ & $\begin{array}{c}3.42 \pm 1.04 \\
(100)\end{array}$ & $\begin{array}{c}3.53 \pm 0.97 \\
(100)\end{array}$ & $\begin{array}{c}3.85 \pm 0.93 \\
(100)\end{array}$ \\
\hline Bacillus & $\begin{array}{c}2.72 \pm 0.25 \\
(57)\end{array}$ & $\begin{array}{c}8.60 \pm 0.36^{* *} \\
(100)\end{array}$ & $\begin{array}{l}8.20 \pm 0.70^{* *} \\
(100)\end{array}$ & $\begin{array}{c}3.08 \pm 0.11 \\
(57)\end{array}$ \\
\hline Yeasts & $\begin{array}{c}4.17 \pm 0.41 \\
\quad(43)\end{array}$ & $\begin{array}{c}3.46 \pm 0.46 \\
(43)\end{array}$ & $\begin{array}{c}3.49 \pm 1.01 \\
(71)\end{array}$ & $\begin{array}{c}4.25 \pm 0.85 \\
(43)\end{array}$ \\
\hline
\end{tabular}

a: Data expressed as mean $\log$ number per gram feces \pm S.D.

${ }^{\mathrm{b}}$ : Figures in parentheses are frequency of occurrence (\%).

Significant difference from the counts before consumption; ${ }^{*} p<0.05,{ }^{*} p<0.001$.

Significant difference from frequency of occurrence before consumption; ${ }^{*} p<0.05$.

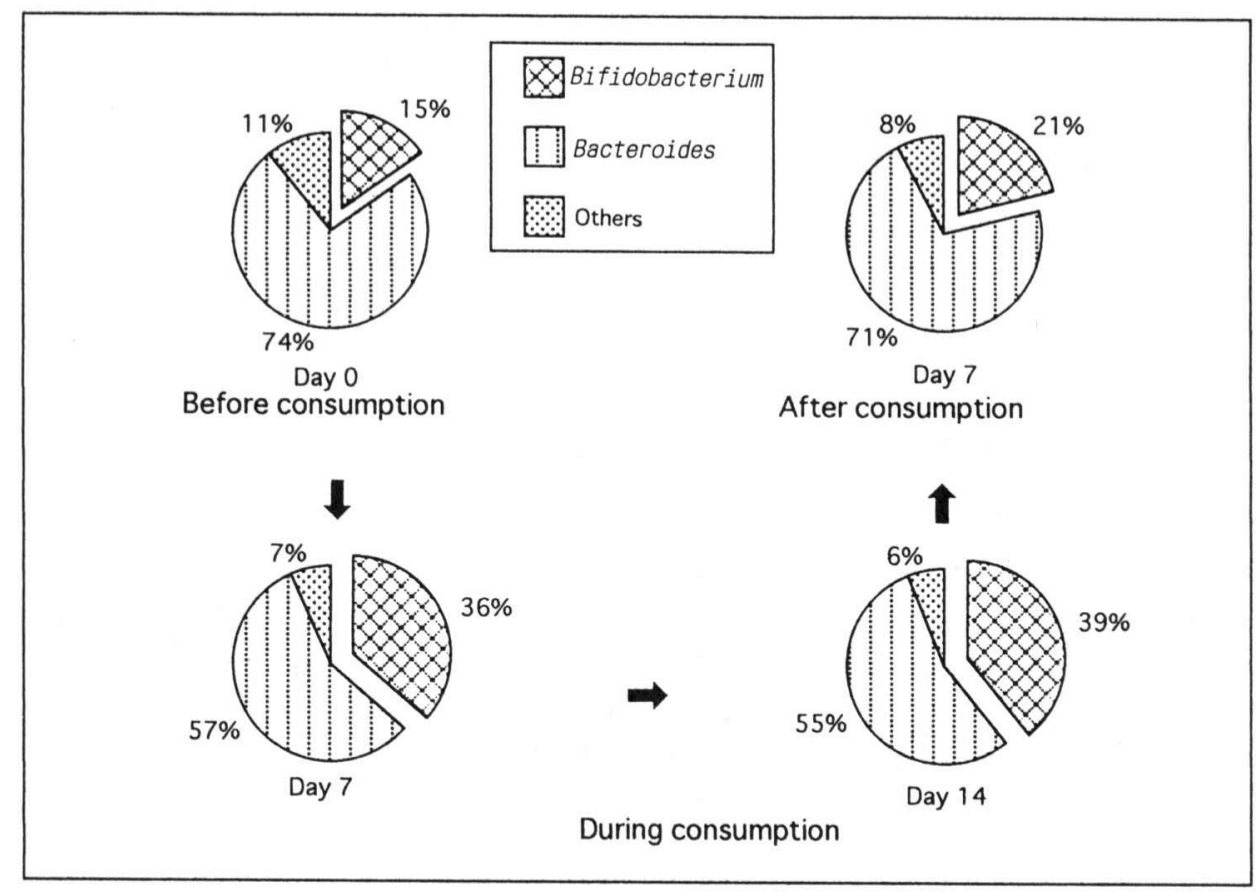

Fig. 1. Changes in fecal flora by Natto consumption.

\section{Statistical analysis of data}

The paired $t$-test and chi-square test were used for statistical analysis of the fecal flora. The paired $t$-test was used for analysis of bacterial metabolites, $\mathrm{pH}$ values, and water content.

\section{Results}

\section{Fecal flora analysis}

The effects of Natto consumption on the composition of fecal flora in seven volunteers are shown in Tables 3 and 4 , and Fig. 1. The levels of B. subtilis $(p<0.001)$ and Bifidobacterium $(p<0.05)$ were significantly increased during the consumption, except for the counts of Bifidobacterium in two volunteers (Figs. 2,3), while the numbers and the frequency of occurrence of lecithinase-positive clostridia $(p<0.05)$, including Clostridium perfringens, were significantly decreased during the consumption (Fig. 4). The counts of Enterobacteriaceae showed a tendency to decrease during the consumption, except for Enterobacteriaceae in three volunteers (Fig. 5), whereas the frequency of occurrence of $B$. subtilis demonstrated an increased tendency during the consumption, when 


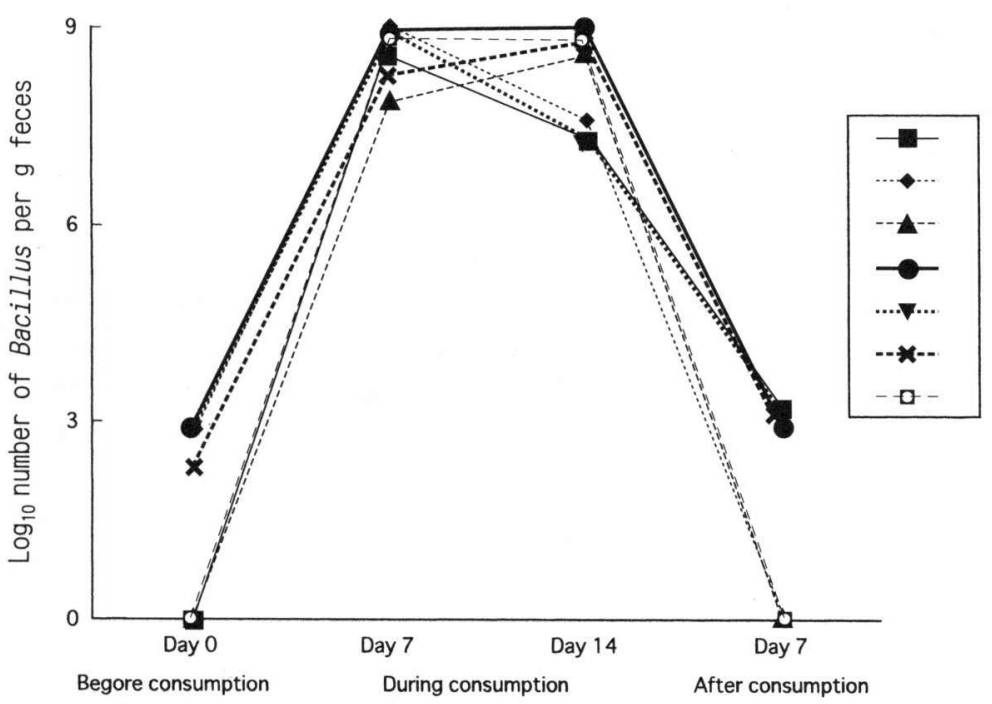

Fig. 2. Change in the levels of Bacillus subtilis during Natto consumption by 7 human volunteers.

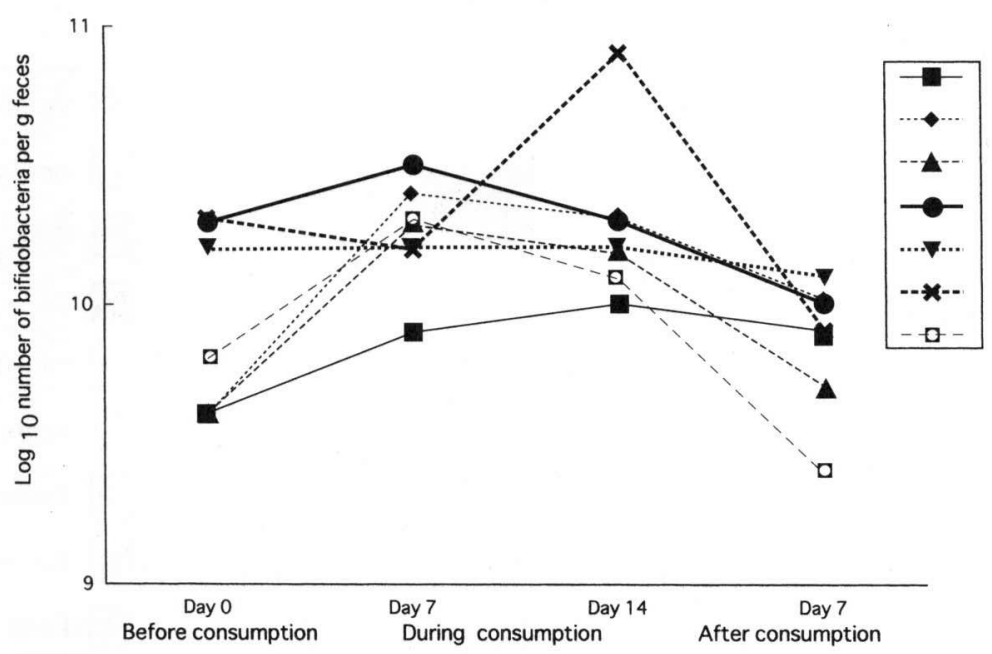

Fig. 3. Change in the levels of Bifidobacterium during Natto consumption by 7 human volunteers.

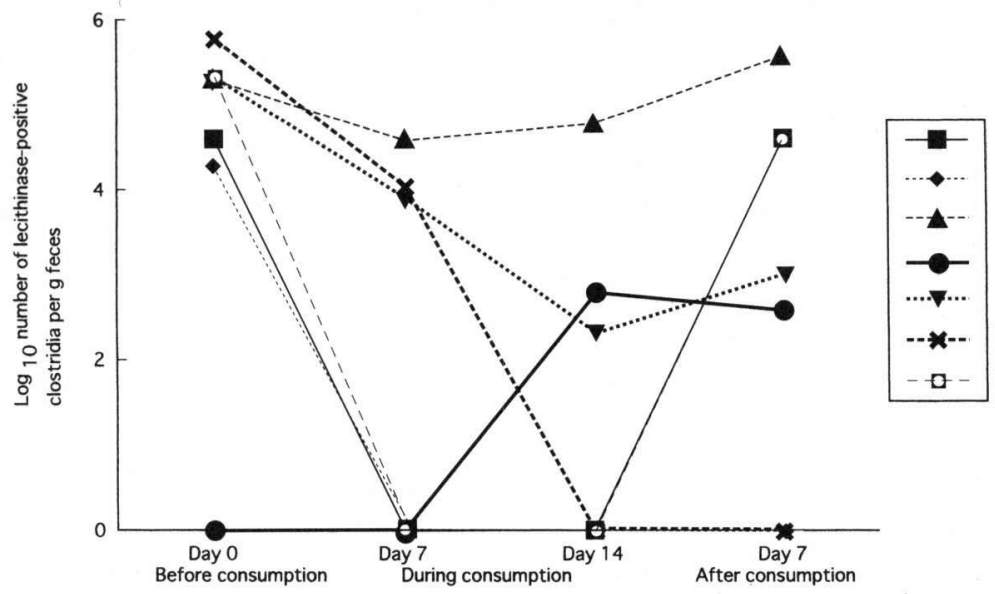

Fig. 4. Change in the levels of lecithinase-positive clostridia during Natto consumption by 7 human volunteers.

compared to the values before the consumption.

No detectable changes occurred in the counts of other organisms or in the total bacteria throughout the experimental periods. 


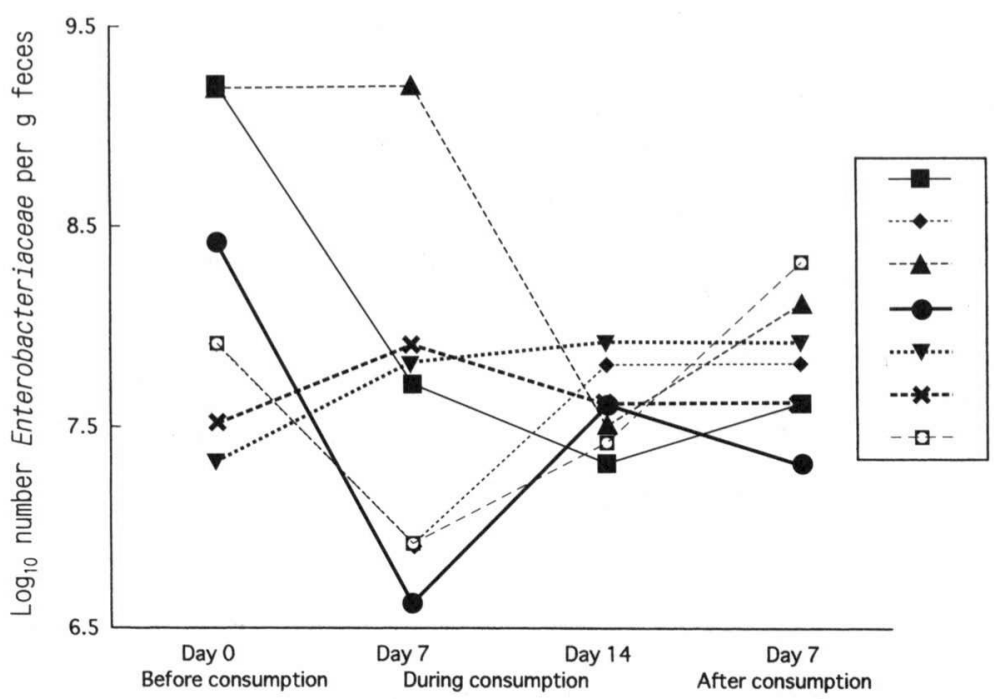

Fig. 5. Change in the levels of Enterobacteriaceae during Natto consumption by 7 human volunteers.

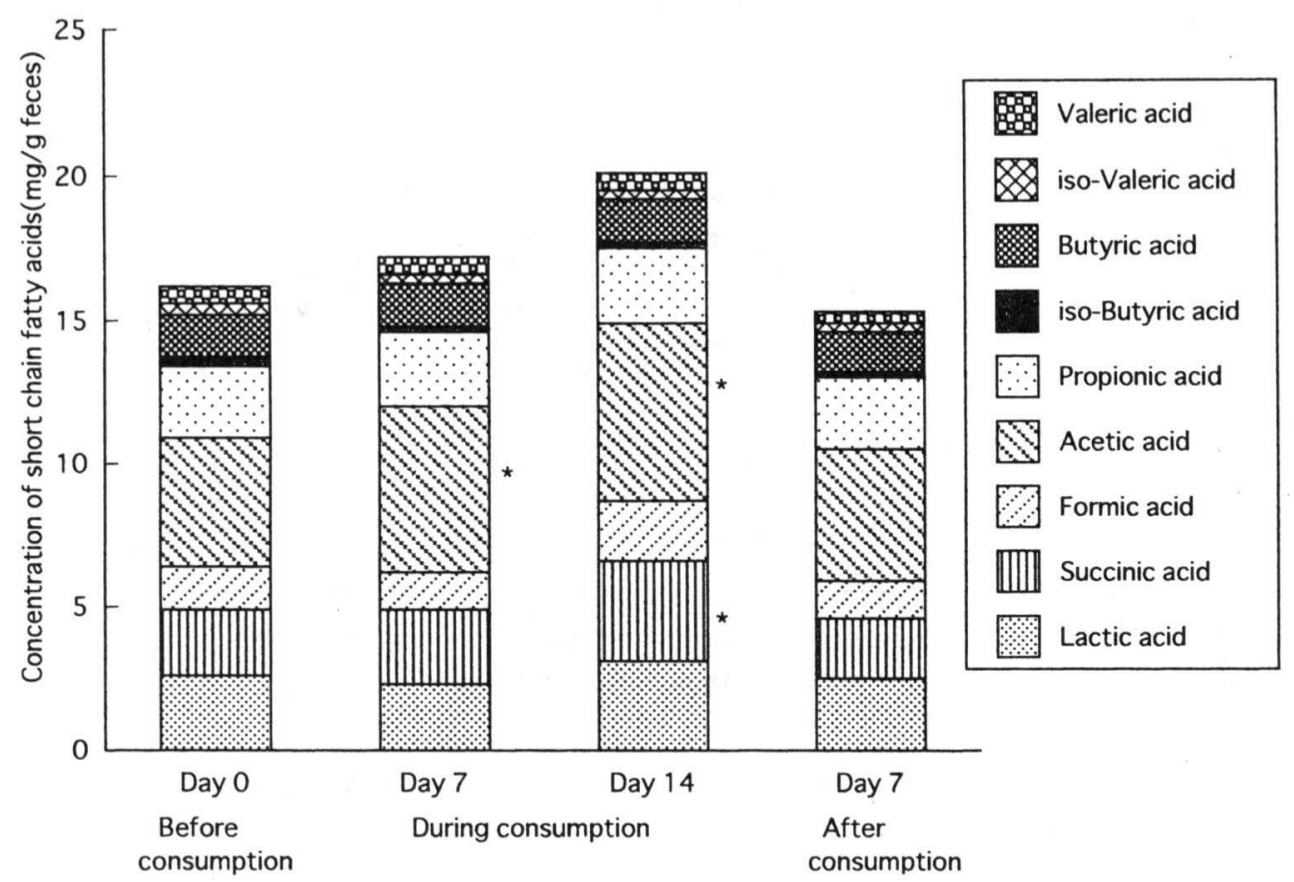

Fig. 6. Change in the concentrations of fecal short chain fatty acids during Natto consumption. Graphs show the mean for 7 human volunteers. Significant difference from the values before consumption; ${ }^{*} p<0.05$.

\section{Fecal organic acids}

The concentrations of fecal acetic acid during the period and total organic acids and succinic acid on day 14 of the consumption showed a significant increase $(p<0.05)$, as shown in Fig. 6 . No significant changes were shown in other fecal SCFA during the consumption.

\section{Fecal putrefactive products}

A significant decrease $(p<0.05)$ in the amounts of fecal indole, skatol and ethylphenol during the consumption, and fecal ammonia and $p$-cresol on day 14 of the consumption were observed when compared to those before the consumption (Figs. 7 and 8). Offensive odor of feces decreased slightly during the consumption.

\section{Fecal water content and pH value}

Fecal $\mathrm{pH}$ values were significantly decreased on day 14 of the consumption compared to those 


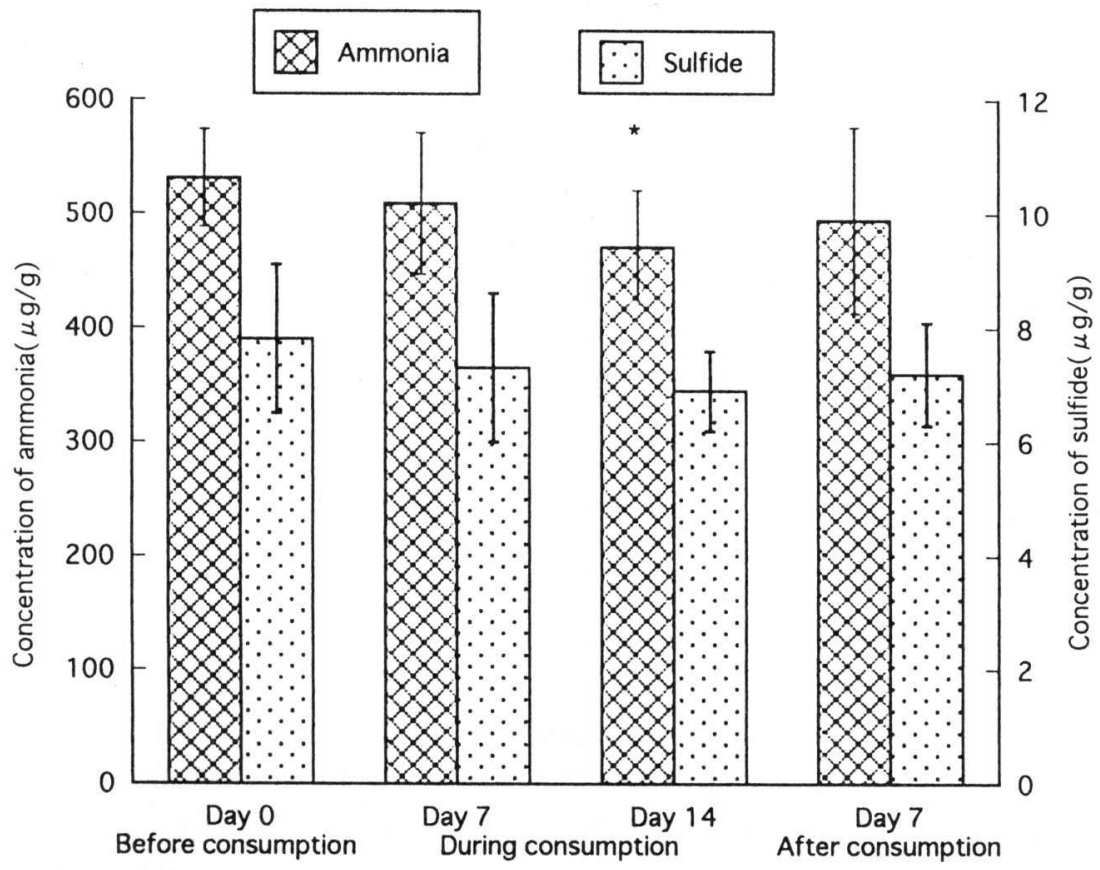

Fig. 7. Change in the concentrations of ammonia and sulfide during Natto consumption. Graphs show the mean \pm S.E. for 7 human volunteers. Significant difference from the values before consumption; ${ }^{*} p<0.05$.

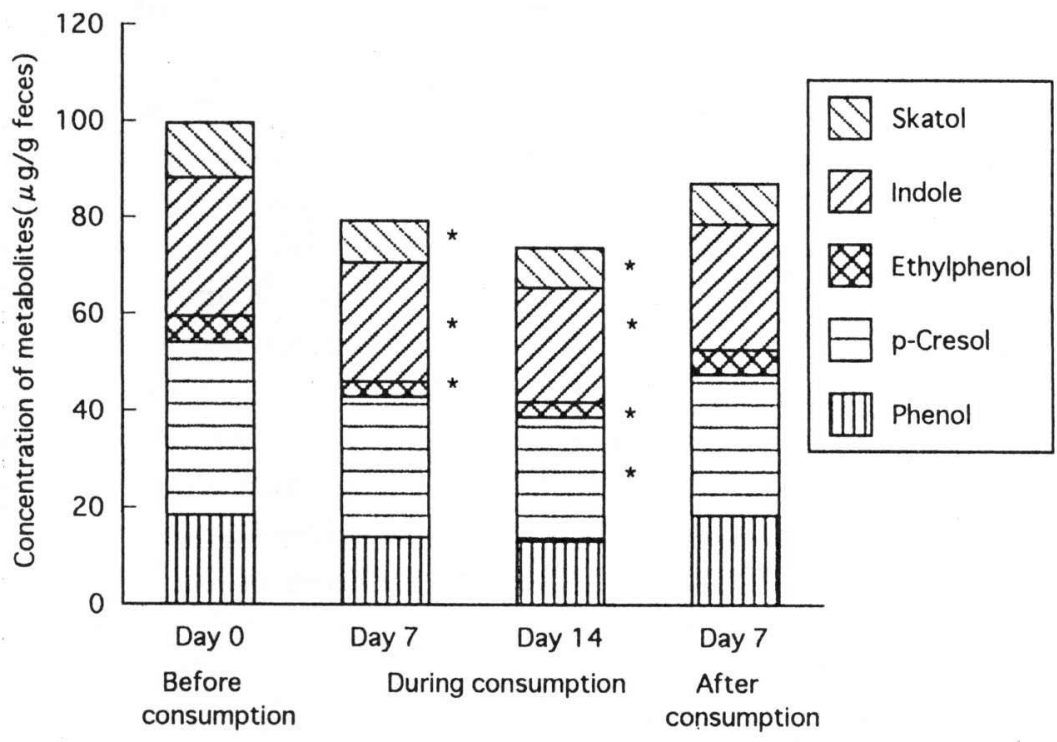

Fig. 8. Change in the concentrations of fecal metabolites during Natto consumption. Putrefactive products are expressed as the mean for 7 human volunteers. Significant difference from the values before consumption; ${ }^{*} p$ $<0.05$.

Table 5. Effect of Natto consumption on fecal pH, weight and water content of seven human volunteers

\begin{tabular}{|c|c|c|c|c|}
\hline \multirow{2}{*}{ Item } & \multirow{2}{*}{$\begin{array}{c}\text { Before consumption } \\
\text { Day } 0\end{array}$} & \multicolumn{2}{|c|}{ During consumption } & \multirow{2}{*}{$\begin{array}{c}\text { After consumption } \\
\text { Day } 7\end{array}$} \\
\hline & & Day 7 & Day 14 & \\
\hline $\mathrm{pH}$ & $6.61 \pm 0.16$ & $6.43 \pm 0.30$ & $6.36 \pm 0.29 *$ & $6.69 \pm 0.37$ \\
\hline Fecal weight (g) & $138.00 \pm 12.20$ & $150.74 \pm 24.94$ & $144.56 \pm 21.80$ & $141.69 \pm 11.31$ \\
\hline Water content (\%) & $73.63 \pm 3.41$ & $75.77 \pm 2.66$ & $75.29 \pm 5.83$ & $74.26 \pm 2.65$ \\
\hline
\end{tabular}

a: Data expressed as mean \pm S.D.

Significant difference from the values before consumption; ${ }^{*} p<0.05$.

before and after the consumption (Table 5). The water content and weight were slightly increased during the consumption. 


\section{Discussion}

The intestinal flora and its metabolic activities are known to play an important role in the host's health $^{6,14,15)}$. Bifidobacterium is composed of a member of predominant flora of humans ${ }^{15)}$. The increase of Bifidobacterium in the intestine brings about a beneficial effect for the host by lowering the $\mathrm{pH}$ in the gut, inhibiting the growth of potential pathogens and stimulating the host's immune systems ${ }^{6,15,20)}$. The amounts of Bifidobacterium in the feces should be above $30 \%$ for the host's health as the results in oligosaccharides ${ }^{7,29}$. On the other hand, a the decrease in the number of lecithinase-positive clostridia, including $C$. perfringens is relative to the reduction of the offensive odor of the feces as is the case with probiotics ${ }^{17,31)}$ and prebiotics ${ }^{9,29,30)}$.

The effects of Natto consumption on the intestinal flora in rats are conflicting. Watanabe et al. ${ }^{34)}$ showed that Natto consumption enhances the growth of Bacillus, Streptococcus, and Lactobacillus, and reduce $E$. coli in rat ceca. In contrast, Isshiki et $a l^{1{ }^{10)}}$ also found a significant increase of Enterobacteriaceae and Bacteroidaceae, and a decrease of bifidobacteria in rat ceca after Natto consumption. The reported results of the intestinal flora in rats are thought to change by various factors such as weaning, diets, antibiotics, pathogens, environmental stressors, and examination method. The stable microbial flora in the intestine of animals is supposed to be effectively maintained by diet and environmental hygiene. In the present study, a significant increase in Bifidobacterium and a decrease in the counts and the detection rate for lecithinase-positive clostridia in humans during Natto consumption were similar to the results in humans administered soybean oligosaccharides $^{8)}$ and raffinose ${ }^{2}$. Major increases in the counts of $B$. subtilis are found during the consumption, which may be considered to mean that there is no effect of acid on the strain in the stomach.

The end-products of the bacterial metabolites such as the SCF A, fermentation gases, and energy are thought to play an important role in intestinal disorders ${ }^{20}$. Cummings et al. ${ }^{4)}$ described that little change in fecal SCFA occurred with variation in diet, and the total SCFA increased parallel to fecal weight. In this study, the increase of fecal acetic acid, succinic acid and total SCFA on Natto consumption was similar to those in humans given lactosucrose ${ }^{7}$. Fecal weight did not increase the reason that the amount of dietary fiber in Natto decreased during fermentation ${ }^{26}$.

Potential toxic substances such as ammonia, sulfide, amines and phenols that are potentially harmful to the host are considered to be important factors in lifestyle-related diseases ${ }^{22}$. In the present study, fecal concentrations of ammonia, phenol, skatol and cresol were decreased in Natto consumption, as has been noted in humans fed yoghurt ${ }^{17}$. These results might be related to the reduction in lecithinase-positive clostridia and Enterobacteriaceae in the large intestine, as noted by Bone $e t a l .^{3}$. It seems that Natto consumption inhibits the metabolic activity of the intestinal flora, resulting in reduction of the effects of aging and causation of lifestyle-related diseases.

Pietroiusti et $a l .{ }^{19)}$ noted that the fecal $\mathrm{pH}$ of humans is not affected by fecal weight, age, sex, or diet of the subjects. Some oligosaccharides ${ }^{7,29)}$, alginate ${ }^{30)}$, chitosan $^{32)}$, and yoghurt ${ }^{17)}$ have been described as effective $\mathrm{pH}$-demoting factors. The level of lowering of fecal $\mathrm{pH}$ values during Natto consumption is 0.25 , which is weaker than oligosaccharides ${ }^{7,29}$ and yoghurt ${ }^{17)}$ consumption.

It may be concluded that Natto consumption contributes to improvement of both the composition and the metabolites of the intestinal flora, resulting in a relative deodorization of human feces.

\section{References}

1) Barnes, S.: Evolution of the health benefits of soy isoflavones. Pro. Soc. Exp. Bio. Med., 217, 386-392 (1998).

2) Benno, Y., Endo, K., Shiragami, N., Sayama, K. and Mitsuoka, T.: Effect of raffinose on human fecal microflora. Bifidobacteria Microflora, 6, 59-63 (1987).

3) Bone, E., Tamm, A. and Hill, M.: The production of urinary phenols by gut bacteria and their possible role in the causation of large bowel cancer. Amer. J. Clin. Nutr., 29, 144-145 (1976).

4) Cummings, J. H.: Nutritional implications of dietary fiber. Amer. J. Clin. Nutr., 31, 21-29 (1978).

5) Fukutake, M., Takahashi, M., Ishida, K., Sugimura, T., Wakabayashi, K. and Kawamura, H.: Quantification of genistein and genistin in soybeans and soybean products. Food Chem. Toxicol., 34, 457-461 (1996). 
6) Fuller, R.: Probiotics in man and animals. J. Appl. Bacteriol., 66, 365-378 (1989).

7) Hara, H., Li, S. T., Sasaki, M., Maruyama, T., Terada, A., Ogata, Y., Fujita, T., Ishigami, H., Hara, K., Fujimori, I. and Mitsuoka, T.: Effect of lactosucrose on fecal flora and fecal metabolites of humans. Bifidobacteria Microflora, 13, 5163 (1994).

8) Hayakawa, K., Mizutani, Y., Wada, K., Masai, T., Yoshihara, I. and Mitsuoka, T.: Effects of soybean oligosaccharides on human faecal flora. Microbial Ecol. Health Dis., 3, 293-383 (1990).

9) Hidaka, H., Eida, T., Takizawa, T., Tokunaga, T. and Tashiro, Y.: Effects of fructo-oligosaccharides on intestinal flora and human health. Bifidobacteria Microflora, 5, 37-50 (1986).

10) Isshiki, S. and Onozaki, H.: Effects of Natto and steamed soybeans on intestinal microflora in rats. Bull. Sugiyama Woman's Univ., 23, 280-282 (1992). (in Japanese)

11) Kanno, A., Takamatsu, H., Takano, N. and Akimoto, T.: Change of saccharides in soybeans during manufacturing of Natto. Nippon Shokuhin Kogyo G., 29, 105-110 (1982). (in Japanese)

12) Kanno, M.: Soybean protein and the lowering of cholesterol. Food Ind., 9, 59-68 (1996). (in Japanese)

13) Minami, Y., Yazawa, K., Tamura, Z., Tanaka, T. and Yamamoto, T.: Selectively of galactosyl-oligosaccharaides by bifidobacteria. Chem. Pharm. Bull., 31, 1688-1691 (1983).

14) Mitsuoka T.: Recent trends in research on intestinal flora. Bifidobacteria Microflora, 1, 3-24 (1982).

15) Mitsuoka T.: Intestinal flora and aging. Nutr. Rev., 50, 438-446 (1992).

16) Mitsuoka, T., Sega, T. and Yamamoto, S.: Eine verbesserte Methodik der qualitativen und quanntitativen Analyse der Darmflora von Menschen und Tieren. Zentralbl. Bakteriol. Parasitenkd. Infektionskr. Hyg. Abt. I, Orig., A195, 455-469 (1965).

17) Morisaki, N., Saito, Y., Terada, A., Hara, H., Osabe, K., Muraishi, K., Iwana, H., Kaneko, T. and Mitsuoka, T.: Effect of yoghurt administration on fecal flora and putrefactive metabolites of senile volunteers. Bifidus, 6, 161-168 (1993). (in Japanese)

18) Nagura, T., Shimizu, Y., Sayama, K. and Benno, Y.: Effect of melibiose on the fecal flora, with special reference to Bifidobacterium spp. and fecal properties in healthy volunteers. Bifidus, 9, 151-159 (1996). (in Japanese)

19) Pietroiusti, A., Caprilli, R., Giuliano, M., Serrano, S. and Vita, S.: Faecal pH in colorectal cancer. Italy J. Gastroenterol., 17, 88-91 (1985).

20) Rowland, I. R. and Wise, A.: The effect of diet on mammalian gut flora and its metabolic activities. CRC Crit. Rev. Toxicol., 16, 31-103 (1985).

21) Sato, T.: Stadies on induction of interferon by "Bacillus natto". Tokyo Med. Coll., 38, 815-826 (1980). (in Japanese)

22) Silverman, S.J. and Andrews, A. W.: Bile acids, comutagenic activity in the Salmonella-mammalian microsome mutagenicity test. J. Natl. Cancer Inst., 59, 1557-1559 (1977).

23) Sumi, H.: Antibacterial activity of Bacillus natto. Growth inhibition against Escherichia coli O-157. Bio. Ind., 14, 47-50 (1997). (in Japanese)

24) Sumi, H., Hanada, H., Nakanishi, K. and Hiratani, H.: Enhancement of the fibrinolytic activity in plasma by oral administration of nattokinase. Acta Haematol., 84, 139-143 (1990).

25) Sumi, H., Yatagai, C., Kishimoto, K. and Kataoka, S.: Research on fermented soybeans and natto as vitamin K (MK-7) medicine. J. Food Sci. Tech., 45, 90 (1998). (in Japanese)

26) Taguchi, K., Kawabata, M., Ohtsuki, K. and Tanaka, Y.: Changes in dietary fiber of natto and tempeh during fermentation. J. Jpn. Soc. Nutr. Food Sci., 39, 203-208 (1986). (in Japanese)

27) Tanaka, R., Takayama, H., Morotomi, M., Kuroshima, T., Ueyama, S., Matsumoto, K., Kuroda, A. and Mutai, M.: Effects of administration of TOS and Bifidobacterium breve 4006 on the human fecal flora. Bifidobacteria Microflora, 2, 17-24 (1983).

28) Terada, A., Hara, H., Ikegame, K., Sasaki, M. and Mitsuoka, M.: Recommended method of enumeration of lecithinasepositive clostridia in human feces. Bifidobacteria Microflora, 13, 29-32 (1994).

29) Terada, A., Hara, H., Kataoka, M. and Mitsuoka, T.: Effect of lactulose on the composition and metabolic activity of the human faecal flora. Microbial Ecol. Health Dis., 5, 43-50 (1992).

30) Terada, A., Hara, H., Kataoka, M. and Mitsuoka, T.: Effect of dietary alginate on faecal microbiota and faecal metabolic activity of humans. Microbial Ecol. Health Dis., 8, 259-266 (1995).

31) Terada, A., Hara, H., Osabe, K., Muraishi, K., Takahashi, M., Kaneko, T. and Mitsuoka, T.: Effect of yoghurt consumption on fecal flora and faecal metabolites in healthy adults. Japan. J. Food Microbiol., 10, 29-34 (1993). (in Japanese)

32) Terada, A., Hara, H., Sato, D., Higashi, T., Nakayama, S., Tsuji, K., Sakamoto, K., Ishioka, E., Maezaki, Y., Tsugita, T. Takekawa, T. and Mitsuoka, T.: Effect of dietarry chitosan on faecal microbiota and faecal metabolites of humans. Microbial Ecol. Health Dis., 8, 15-21 (1995).

33) Tsuchihashi, N., Watanabe, T., Shimizu, K. and Takai, Y.: Effect of living cells of Bacillus on rats. Bull. Chiba Prefectural Junior College, 5, 3-8 (1986). (in Japanese)

34) Watanabe, T., Tuchihashi, N., Kanno, A. and Takai, Y.: Effects of natto and steamed soybeans on growth and cecal bacterial flora of rats. J. Jpn. Soc. Nutr. Food Sci., 48, 123-289 (1995). (in Japanese)

35) Yamanishi, R., Huang,T., Tsuji, H., Bando, N. and Ogawa, T.: Reduction of the soybean allergenicity by the fermentation 
with Bacillus natto. Food Sci. llus natto. Food Sci. Technol. Int., 1, 14-17 (1995). (in Japanese)

36) Yoshihara, I.: Isothermal gas chromatographic analysis of putrefactive products in gastrointestinal contents and urine using the same dual column system. Agric. Biol. Chem., 45, 1873-1875 (1981).

\title{
納豆摂取がヒト腸内フローラおよび腐敗産物に及ぼす影響
}

\author{
寺田厚・山本政重・吉村栄治 \\ （日本獣医畜産大学畜産食品工学科）
}

健康成人 7 名に納豆 $(50 \mathrm{~g} /$ 日) を 2 週間摄取させ, 腸内フローラおよび腐敗産物に及ぼす影響を検討した. 腸内フ ローラでは納豆摂取中に Bifidobacterium $(p<0.05)$, Bacillus subtillis $(B$. natto; $p<0.001)$ は有意に増加し，レシチ ナーゼ陽性 clostridia $(p<0.05)$ の菌数と検出率は有意に減少した。 また，納豆摄取中に Enterobacteriaceae は減少傾 向を示し, Bacillus subtillis の検出率は増加傾向を示した. その他の細菌群の変動は認められなかった.

短鎖脂肪酸では納豆摄取中に酷酸 $(p<0.05)$, 摄取 2 週目に総有機酸 $(p<0.05)$ とコ八ク酸 $(p<0.05)$ は有意に増加 した. 腐敗産物では納豆摄取中にフェノール, エチルフェノール，スカトール $(p<0.05)$ は有意に減少し，摄取 2 週目 ではアンモニア, クレゾール $(p<0.05)$ が有意に減少した. $\mathrm{pH}(p<0.05)$ は納豆摄取 2 週目に有意に低下した.

以上より, 納豆摂取は腸内フローラの構成と代謝活性によって, 腸内環境の改善と便の脱臭効果が示唆された。 